\title{
Developing Android Educational Games Application for Enhancing Children's Healthy Food Skill
}

\section{Annis Kandriasari, Nur Riska, and Yeni Yulianti}

Culinary Arts Vocational Education Study Program, Faculty of Engineering, State University of Jakarta

\section{Abstract}

This study aims to develop Edu game of "Ayo Memasak Bersama" that is feasible and effective to improve procedural cognitive about making a healthy food menu for kindergarten children in group B. The research design used Research and Development (R\&D) with Borg \& Gal model. Respondents were 20 children. Data collection techniques used include observation, interviews, and questionnaires. The product produced is feasible, the material expert's feasibility test of $98 \%$ with the criteria of "Fulfilling the feasibility aspect." The media expert has obtained a feasibility

Corresponding Author: Annis Kandriasari annis.kandria@gmail.com

Received: 11 January 2019 Accepted: 14 February 2019 Published: 25 March 2019 Publishing services provided by Knowledge E

(c) Annis Kandriasari et al. This article is distributed under the terms of the

Attribution License, which permits unrestricted use and redistribution provided that the original author and source are credited.

Selection and Peer-review under the responsibility of the 3rd ICTVET 2018 Conference Committee.

\section{G OPEN ACCESS} test of $96 \%$ with the criteria of "Fulfilling the feasibility aspect." Based on the feasibility assessment of operational field trials (final field trials) by students, the results revealed 95\% with the criteria of "Feasible." By using android Edu game of "Ayo Memasak Bersama," there is an increase of effectiveness in procedural cognitive early childhood with a value of $88.4 \%$ with the criteria of "high product effectiveness."

Keywords: development, Android educational games, healthy food, increasing knowledge, skills, children aged $5-6$ years

\section{Introduction}

An educational game is exciting to develop. The Massachusetts Institute of Technology (MIT) proved that games are beneficial to improve players' logic and understanding of a problem through a game project called Scratch [1]. Children enjoy the game and will continue to do it wherever they have the opportunity. It relates to PAUD slogan of playing while learning and learning through play [2]. Educational games gave about healthy food. Healthy food is hygienic and nutritious food. The food we will eat must contain a complete nutritional composition, which consists of carbohydrates, fats, proteins, vitamins, minerals, and water. The way to do to provide an introduction to healthy foods is (1) shows various kinds of healthy food; (2) how to choose healthy food; and (3) the benefits of nutrition for life. 
From the description above, researchers are interested in building an early childhood learning educational game about healthy food based on Android. In Indonesia, the Android operating system has become the most popular operating system with a percentage of Android users around 52\% [3]. Many game features are not only playing entertainment, but there are many games to hone the mind and logic that can introduce material to be more interesting to be accepted and understood especially by children who are still at an early age [4].

Based on observations, there are several obstacles in Amanah Kindergarten. First, each material is limited once a week. Submitting the learning theme is not optimal because each learning theme has much material. Second, the learning media is only in the form of pictures, child worksheets and examples of concrete objects that are around the school. It is because teachers have difficulty developing new and efficient learning media. According to Arsyad, the development of science and technology increasingly encourages renewal efforts in the use of technological results in the learning process [5]. Therefore, the media that used is an android educational game.

Based on the existing problems, a study entitled "Developing Android Educational Games Application for Enhancing Children's Healthy Food Skill" developed. It aimed to improve procedural cognitive abilities in early childhood. With the increasing procedural ability of children in making healthy food menus, children are expected to be able to make these healthy food menus independently in their daily lives.

\section{Methods and Equipment}

\subsection{Methods}

This research used Research and Development (R\&D) with Borg \& Gall model [6]. This is the following stages: 1) Data collection; 2) Product design planning; 3) Product development; 4) Initial field trial; 5) Revision of the initial product; 6) Main field trials; 7) Revision of main products; 8) Operational field trials; 9) Refinement of the final product; and 10) Dissemination and implementation.

\subsection{Data collection}

Data collection is done to determine the fields and scope of the problem in learning. The things that considered are about healthy food, including the suitability of learning 
needs with the appropriate curriculum, and the stages of student development. The steps taken in this stage are field studies, needs analysis and literature study.

\subsection{Product design planning}

The researchers examined the ingredients to compile in an android educational game about a healthy food menu. For example, product use objectives, product user objectives, product component descriptions, and their use, and product development stages.

\subsection{Product development}

A product design development developed based on the results of needs analysis and design in the preliminary study. The completeness of the initial product is made based on the components needed. For example, material concepts, storyboard making, software and hardware requirements, and evaluation by experts.

\subsection{Initial field trial}

The initial field trial is a trial carried out on small groups before the larger group by using a snowball sampling technique. 4 of 20 children as a sample in Amanah Kindergarten group B will take. They selected based on the results of interviews with three parents of students, and one student will choose by the teacher of class B with the criteria of children who are very active using smartphones to play games.

\subsection{Revision of the initial product}

The data collected at the initial field trial phase that analyzed. It used as a reference to improve the product. The revised results on this product will use at the main field trial stage.

\subsection{Main field trial}

During the field trial phase, six children were carried out. Children are people who do not take the initial field trial, and they are chosen randomly by the teacher. At the time of the implementation of this field trial, children observed when they used educational games as learning media. 


\subsection{Revision of main product}

The results of field trials used as a reference in fixing android-based educational games. Product revision aims to correct deficiencies in educational games before heading to the next stage.

\subsection{Operational field trial}

This stage is the latest trial in the development of android educational game products. In this operational field trial, it involved ten children who will carry out experimental design (before-after). It obtained the results of early childhood procedural cognitive improvement after using the media in the form of educational games, "Ayo Memasak Bersama", compared to the use of media previously used, namely a picture of a healthy food menu.

\subsection{Refinement of the final product}

Product results can see if the operational field tested. This stage tested will see the results, whether this product is feasible or not to be used and can improve children's procedural cognitive in preparing their healthy food menu through this android educational game.

\subsection{Dissemination and implementation}

Product results can see if the operational field $\mathrm{h}$ tested. At this stage, the products that tested will see the results, whether this product is feasible or not to be used and can improve children's procedural cognitive in preparing their healthy food menu through this android educational game.

\section{Results}

The results of this study are an android educational game about healthy food in Amanah Kindergarten for early childhood. It is in the form of Android.apk format on smartphones. 


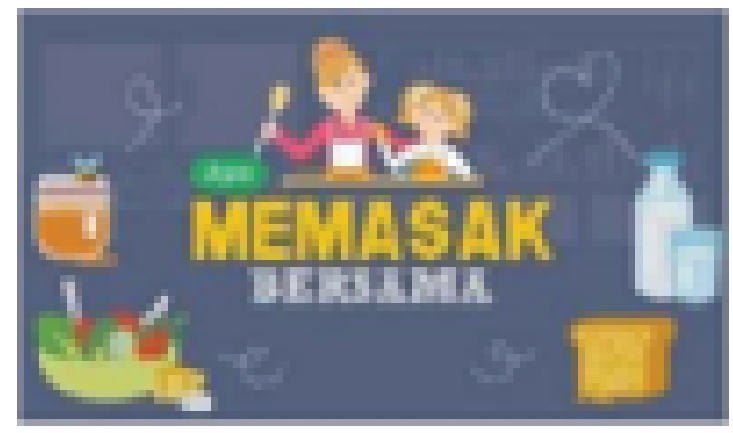

Figure 1: Opening Display.

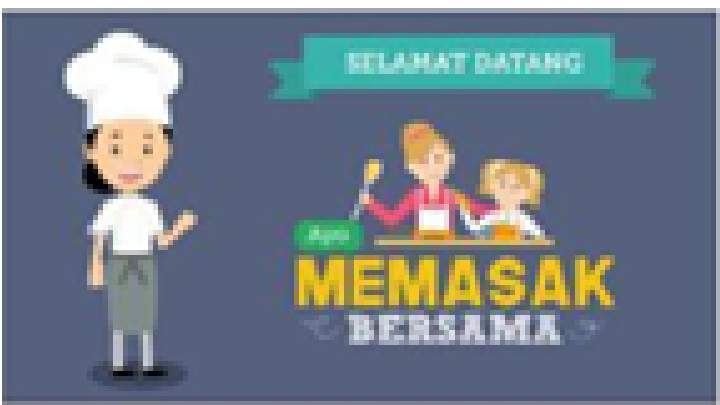

Figure 2: Welcoming Display.

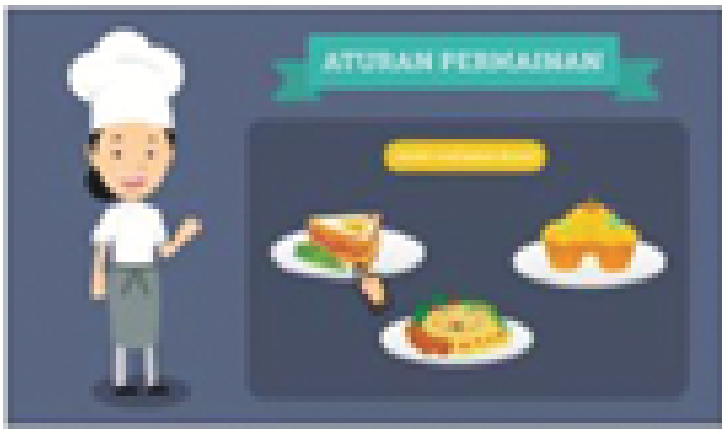

Figure 3: Game Rules Display.

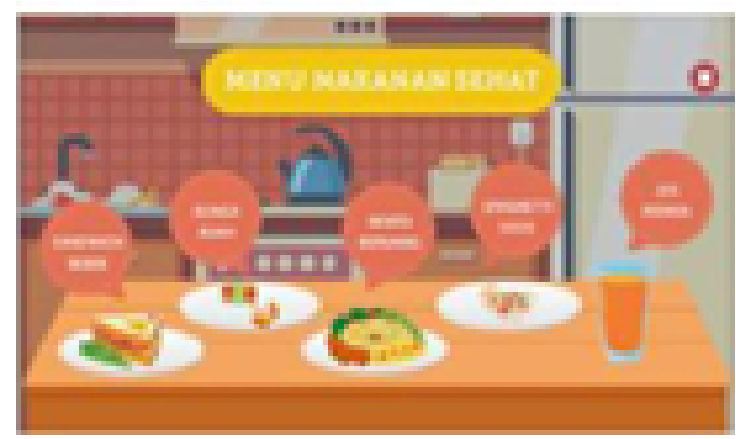

Figure 4: Main Menu Display. 


\subsection{Trial results}

Field trials carried out three times in the form of observations made by asking directly from students of Group B Amanah Kindergarten after using an android educational game. Three field trials consisting of (1) Initial field trials. It consisted of 4 respondents. The results of observations from the initial field trials obtained a high percentage of $90 \%$ and entered the criteria of "Feasible." (2) Main field trials. It consisted of 6 respondents. The results of observations from the main field trials obtained a high percentage of $85 \%$ and entered the criteria of "Feasible." (3) Operational field trials. It consisted consisting of 10 respondents. In this trial observations, it made after the effectiveness test. The results of observations from operational field trials obtained a high percentage of $95 \%$ and entered the criteria of "Feasible."

TABLE 1: Guidelines for Respondent Test Criteria.

Score
$X>75 \%$
$X \leq 75 \%$

\section{Criteria}

Feasible

Not feasible

\subsection{Analysis results of the effect on android educational games application on healthy food skills for children aged 5-6 years}

Kolmogorov's normality test conducted to determine whether the population is normally distributed or not. Distribution said to be normal if the value of sig $>0.05$, then the parametric statistical test is used. However, if the data is not normally distributed, the sig value is $<0.05$, the nonparametric statistical test used. The results of the normality test on the distribution of skill data before and after the intervention obtained the significance value of 0.732 . Thus the significance value of skills before and after intervention using the android educational games application media is higher than 0.05 . So that data can be said to be normally distributed. Hypothesis analysis using parametric tests can continue it. Comparison of children's skills after 5-6 years in using android games applications before and after the provision of media about healthy foods can see in Table 2 below.

TABLE 2: Comparison Skill of Android Educational Games Application.

\begin{tabular}{|l|c|c|c|}
\hline & Average & $\begin{array}{c}\text { Standard } \\
\text { Deviation }\end{array}$ & P-Score \\
\hline Before & 10.90 & 1.912 & $\mathbf{0 . 0 0 1}$ \\
\hline After & 22.10 & 1.449 & \\
\hline
\end{tabular}


Paired Sample Test results obtained $p=0.001<\alpha(0.05)$. There is a significant effect on the average score of skills of children aged 5-6 years in processing healthy food after giving intervention in the form of educational media games android application.

\subsection{Effectiveness result of implementing android games application on children skills of 5-6 years old}

The product effectiveness used experimental design (before-after). Experimental design (before- after) was carried out during operational field trials with the aim of getting comparative data from the media previously used with android educational games. Based on these values, the use of an android educational game media about healthy food is $=221: 250=0.884$ or $88.4 \%$ of the expected criteria. It can see that the use of previous media in the form of images $=43.6 \%$ than expected with a low media effectiveness category and an android educational game $=88.4 \%$ than expected with high media effectiveness. The value of each healthy food menu can see in table 3 .

TABLE 3: New Media Release Media Comparison.

\begin{tabular}{|l|l|}
\hline No. & Healthy Food Menu \\
\hline 1. & Sandwich Bebek \\
\hline 2. & Bunga Buah \\
\hline 3. & Bento Beruang \\
\hline 4. & Spaghetti Sosis \\
\hline 5. & Jus Pepaya \\
\hline & Average \\
\hline
\end{tabular}

\begin{tabular}{|c|c|}
\hline \multicolumn{2}{|c|}{ Old Media } \\
\hline Total & $\%$ \\
\hline 19 & $38 \%$ \\
\hline 25 & $50 \%$ \\
\hline 17 & $34 \%$ \\
\hline 16 & $32 \%$ \\
\hline 32 & $64 \%$ \\
\hline & $43.6 \%$ \\
\hline
\end{tabular}

\begin{tabular}{|c|c|}
\hline \multicolumn{2}{|c|}{ New Media } \\
\hline Total & $\%$ \\
\hline 42 & $84 \%$ \\
\hline 48 & $96 \%$ \\
\hline 41 & $82 \%$ \\
\hline 40 & $80 \%$ \\
\hline 50 & $100 \%$ \\
\hline & $88.4 \%$ \\
\hline
\end{tabular}

Based on the table, it can see that the new media using android educational games is much higher than the old media using images. In conclusion, the use of learning media in the form of android educational games can improve the skills of children aged 5-6 years.

\subsection{Results analysis of differences in children's healthy food skill aged 5-6 years toward android gaming application}

Correlated (related) t-test conducted to prove the significance of differences in the use of old media, namely image media and new media, namely an android educational game about healthy food. Calculations used SPSS so that prices can be found to calculate $\mathrm{t}[6]$. Testing using the right-sided $\mathrm{t}$ - test correlated test. The alternative hypothesis $(\mathrm{Ha})$ reads "better" [6]. Significance level of $5 \%=0.05$ then, table $=1.86$. 
Based on the calculation of $t$ count $=-15.155$ is located in the receiving area Ha which can see in the figure.
Ha receiving area
Ho receiving area

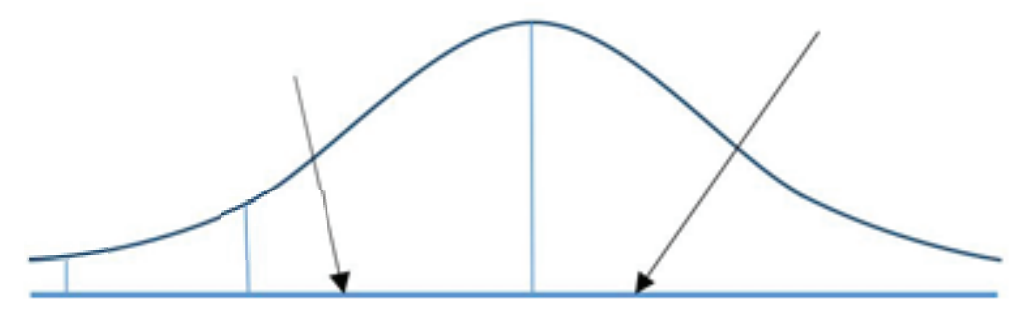

$-15.155 \quad 1.86$

Figure 5: Right Party Hypothesis Test; $t$-count -15.155 falls in the Ha receiving area, so Ha is accepted.

\section{Discussion}

Field trials carried out three times in the form of observations made by asking the students of Group B Amanah kindergarten directly after using an android educational game showing the results of the media "decent." There are several advantages of educational games compared to conventional education methods. One of the main advantages of educational games is the visualization of real problems. The Massachusetts Institute of Technology (MIT) has proven that games are beneficial to improve players' logic and understanding of a problem through a game project called Scratch. Based on the results of previous studies, there is no doubt that educational games can support the educational process. Educational games excel in several aspects when compared to conventional learning methods. One significant advantage is the existence of animation that can improve memory so that children can store subject matter for a long time compared to conventional teaching methods [7]. Educational games are one form of the game that is used as a means of supporting learning, both formally and non-formally. Treatment through educational games is only given during intervention. Moreover, after the observation is complete, it will be measured by the ability of the child by using the percentage of total questions answered correctly [8].

Based on the results of the hypothesis it can be seen that the interest in learning in children with the application of Android-based educational games is better than in children who do not give treatment. Also, the paired sample hypothesis test shows that there is an increase in skills in the children who gave treatment, namely the experimental group. The results showed there were significant differences in the use of old media using images and new media using android educational games about healthy food, 
where the use of android educational game media about healthy food is better than the use of media in the form of pictures for five healthy food menus on the skills of children aged $5-6$ years.

Clarified by the research conducted of Fitri Yeni's research in 2013, it is proven that giving intervention through educational games was effective in increasing the number addition ability of DII class learning difficulties at MIN Koto Luar, Pauh District. With the implementation of educational games, children are more eager to learn and understand learning material. Because in essence, early childhood is indeed in the stage of playing. So that any activity is carried out by playing method can attract children's interest in learning [9].

The results of this study supported by research conducted by Petrovska, Sivevska, and Cackov (2013) from the University of Goce Delcev. The researchers stated that the game could meet the biological and psychological needs of children and contribute to their mental, emotional, social and moral development. Although the research conducted by researchers with the research conducted by Petrovska, Svenska, and Chekov differed in the dependent variable, both of these studies found the benefits of games for education, unusually early childhood education. So that the hypothesis used in this study can be accepted, namely an effective educational game to increase interest in early childhood learning, especially kindergarten children in group B in Aisyiyah Nusukan 1 and three kindergartens Surakarta 2015/2016 Academic Year [10].

\section{Conclusion}

Based on the results of the research and development that has been done, the following conclusions can be drawn: (1) Development of an android educational game on healthy food is carried out using the Research and Development with Borg \& Gall model with the following stages: a) Data collection; b) Product design planning; c) Product development; d) Initial field trial; e) Revision of the initial product; f) Main field trials; g) Revision of main products; h) Operational field trials; i) Refinement of the final product; and j) Dissemination and implementation. (2) Android educational game about healthy food is effective to improve the skills of children aged 5-6 years about making a healthy food menu based on the calculation of the comparison of the average value of both media. From these calculations it can be seen that the use of previous media in the form of images get a value of $43.6 \%$ with the assessment criteria "Effectiveness of low products" and the media based Android education game on healthy foods get a value of $88.4 \%$ with the assessment criteria "High effectiveness product." 


\section{Funding}

This research has been funded by the BLU Faculty of Engineering, State University of Jakarta.

\section{Acknowledgment}

The authors would like to thank the Faculty of Engineering for funding the research through the BLU fund of independent research. The authors would like to thank their colleagues for their contribution and support to the research, and also the reviewers who gave their valuable inputs to the manuscript and helped in completing the paper.

\section{Conflict of Interest}

The authors have no conflict of interest to declare.

\section{References}

[1] Clark, R. E. (2006). Evaluating the Learning and Motivation Effects of Serious Games. Rosier school of Education Center for Creative Technologies Available online at: http://projects.ict.usc.edu/itgs/talks/Clark_Serious\{\%\}20Games\{\%\}20Evaluation.ppt

[2] Sujiono, Y. N. (2009). Konsep Dasar Pendidikan Anak Usia Dini. Jakarta: Indeks.

[3] Saptawati, Bardosono. (2014). Penilaian Status Gizi Balita, Diakses dari http://staff.ui.ac.id/system/files/users/saptawati.bardosono/material/ penilaianstatusgizibalitaantropometri.pdf. Pada 09 April 2018.

[4] Kurniawati, S., Calvin, dan Yustina, M, 2012. Pengembangan Aplikasi Pembelajaran Bahasa Inggris Secara Self-Learning Pada Sistem Operasi Android, Skripsi_S1, UNIKOM, Bandung.

[5] Arsyad, Azhar. (2011). Media Pembelajaran. Jakarta: PT Raja Grafindo Persada.

[6] Sugiyono. (2016). Metode Penelitian Kuntitatif, Kualitatif, dan R\&D. Bandung: Alfabeta.

[7] Donald Clark. (2006). Game and e-learning. Sunderland: Caspian Learning. www. caspianlearning.co.uk.

[8] Cartono, Randi. 2013. Jagat Permainan Interaktif. Jakarta: PT. Bumi Aksara.

[9] Fitri Yeni, Yarmis Hasan, dan Tarmansyah. 2013. Efektifitas Game Edukasi Untuk Meningkatkan Kemampuan Penjumlajan Bagi Anak Kesulitan Belajar Di Min Koto 
Luar, Kecamatan Pauh. E- JUPEKhu (JURNAL ILMIAH PENDIDIKAN KHUSUS). Vol. 2, no. 3, September 2013. Halaman: 501-513. http://ejournal.unp.ac.id/index.php/ jupekhu.

[10] Petrovska, S., Sivevska, D., \& Cackov, O. (2013). Role of the Game in the Development of Preschool Child. Lumen Research Center, 880-884. 